\title{
UPAYA MENINGKATKAN HASIL BELAJAR ILMU PENGETAHUAN ALAM DENGAN MENGGUNAKAN MEDIA GAMBAR SISWA KELAS IV SDN 101771 TEMBUNG
}

\author{
Nurlaili Pulungan \\ Surel: sdnmedanstate@yahoo.co.id
}

\begin{abstract}
ABSTRAK
Tujuan penelitian ini adalah untuk meningkatkan hasil belajar Ilmu Pengetahuan Alam (IPA) dengan menggunakan media gambar pada siswa kelas IV SDN 101771 Tembung Tahun Pembelajaran 2013/2014. Penelitian ini adalah Penelitian Tindakan Kelas. Hasil penelitian dengan menggunakan media gambar dapat meningkatkan hasil belajar IPA siswa pada materi energi alternatif, pada siklus I terdapat 10 orang (40\%) yang belum tuntasdan sebanyak 15 orang $(60 \%)$ yang telah tuntas dengan rata-rata kelas 66,8. Pada siklus II sebanyak 24 orang (96\%) yang telah tuntas dan terdapat 1 orang siswa (4\%) yang belum tuntas dengan rata-rata kelas 82,4 .
\end{abstract}

Kata Kunci : Hasil Belajar IPA, Media Gambar

\section{PENDAHULUAN}

Sekolah merupakan lembaga pendidikan yang mempunyai tugas untuk menghantarkan peserta didik mengembangkan segala potensi yang dimilikinya. Sekolah juga dipercaya sebagai satu-satunya cara agar manusia pada zaman sekarang dapat hidup mantap dimasa yang akan datang. Keberhasilan pendidikan di sekolah sangat tergantung pada proses belajar mengajar di kelas. Dalam pembelajaran di sekolah terdapat banyak unsur yang saling berkaitan dan menentukan keberhasilan dalam proses belajar mengajar. Unsur-unsur tersebut adalah pendidik (guru), peserta didik (siswa), kurikulum pengajaran, tes dan lingkungan. Siswa sebagai subjek dalam proses pembelajaran tersebut juga sangat berperan dalam keberhasilan belajar mengajar.

Salah satu tugas pendidik atau guru adalah menciptakan suasana pembelajaran yang dapat memotivasi siswa untuk senantiasa belajar dengan baik dan bersemangat. Suasana pembelajaran yang demikian akan berdampak positif dalam pencapaian prestasi belajar yang optimal. Oleh karena itu guru sebaiknya memiliki kemampuan dalam memilih metode dan media pembelajaran yang tepat. Ketidaktepatan dalam penggunaan metode dan media pembelajaran akan menimbulkan kejenuhan bagi siswa dalam menerima materi yang disampaikan sehingga materi kurang dapat dipahami oleh siswa. Prinsip pengajaran yang baik adalah jika proses belajar mengajar mampu mengembangkan konsep generalisasi dari bahan abstrak menjadi hal yang jelas dan nyata. Maksudnya, proses belajar mengajar dapat membawa perubahan pada diri anak dari tidak tahu menjadi tahu dan dari pemahaman yang bersifat umum menjadi khusus. Media pembelajaran 
dapat membantu menjelaskan bahan yang abstrak menjadi konkrit.

Salah satu mata pelajaran yang diajarkan di sekolah dasar adalah Ilmu Pengetahuan Alam (IPA). IPA merupakan ilmu yang mempelajari tentang alam, yang berhubungan dengan kehidupan dan lingkungan sekitar dan peristiwaperistiwa yang terjadi di alam. Pelajaran IPA dapat menjadi pengalaman langsung bagi peserta didik dan dapat diterapkan dalam kehidupan sehari-hari, pembelajaran ini ditekankan pada pemberian pengalaman langsung kepada siswa.

Dalam proses belajar mengajar terdapat komponen-komponen yang saling terkait yang meliputi tujuan pengajaran, guru dan peserta didik, bahan pelajaran, metode/strategi belajar mengajar, alat atau media, sumber pelajaran dan evaluasi. Oleh karena itu proses belajar mengajar yang aktif ditandai adanya keterlibatan siswa secara komprehensif baik fisik, mental dan emosionalnya. Salah satu diantaranya dapat dilakukan guru dengan memanfaatkan media pembelajaran.

Pemakaian media pembelajaran dalam proses belajar mengajar dapat membangkitkan keinginan dan minat yang baru, membangkitkan motivasi dan rangsangan kegiatan belajar dan bahkan membawa pengaruh-pengaruh psikologis terhadap siswa. Media pembelajaran merupakan wahana dalam menyampaikan informasi/pesan pembelajaran pada siswa. Dengan adanya media dalam proses belajar mengajar, diharapkan membantu guru dalam meningkatkan pemahaman belajar siswanya. Oleh karena itu guru seharusnya menggunakan media dalam setiap proses belajar mengajar demi tercapainya tujuan pembelajaran. Untuk mempermudah siswa memahami pelajaran, guru dapat menggunakan media gambar yang konkret, karena dengan menggunakan media dapat memberi semangat belajar dan siswa akan terlibat secara aktif dalam proses belajar mengajar.

Berdasarkan hasil observasi yang peneliti lakukan di SD Negeri No. 101771 tembung, bahwa dalam kegiatan belajar mengajar guru tidak menggunakan media pembelajaran, salah satunya penggunaan media gambar. Dimana guru masih menyampaikan pesan atau isi pelajaran hanya dengan kata-kata semata (verbalisme), situasi seperti ini dengan mudah dapat mengganggu konsentrasi belajar siswa, sehingga siswa kurang termotivasi untuk belajar dan siswa kurang menguasai materi yang diajarkan. Selanjutnya berdasarkan wawancara dengan guru kelas IV ternyata guru masih kurang terampil untuk membuat media gambar dalam proses belajar mengajar sehingga pemahaman siswa terhadap materi yang diajarkan tidak tercapai semaksimal mungkin dikarenakan pemahaman siswa dalam menguasai materi energi alternatif masih sangat rendah dan siswa mengalami kesulitan dalam 
menyelesaikan soal-soal latihan. Hal ini dapat dilihat dari hasil ulangan harian yang diperoleh siswa tidak sesuai dengan standar ketuntasan belajar siswa. Dimana hasil ulangan yang diperoleh siswa masih dibawah rata-rata KKM (Kriteria Ketuntasan Minimal) yaitu dibawah 65. Dari 25 orang siswa hanya terdapat 5 orang siswa yang sudah tuntas mendapat nilai rata-rata 65 sedangkan 20 orang siswa masih belum tuntas karena nilai yang dicapai masih dibawah rata-rata KKM yaitu dibawah nilai rata-rata 65. Seharusnya belajar dikatakan tuntas apabila siswa secara keseluruhan mampu mendapatkan nilai rata-rata 65. Dengan demikian dapat dikatakan bahwa hasil belajar siswa pada pembelajaran tersebut masih sangat rendah.

Untuk mengatasi masalah dalam pembelajaran tersebut guru perlu bervariasi dalam menggunakan metode dan media pembelajaran. Salah satunya adalah dengan memanfaatkan pemakaian media pembelajaran seperti media gambar yang dapat membantu guru dan siswa dalam proses belajar mengajar karena gambar memiliki kelebihan yaitu sifatnya konkret, gambar dapat mengatasi ruang dan waktu, mengatasi keterbatasan pengamatan, memperjelas suatu masalah sehingga dapat mencegah atau membetulkan kesalahpahaman. Mengacu pada kelebihan media gambar maka dapat dimungkinkan pemanfaatan media gambar dalam pembelajaran IPA akan meningkatkan hasil belajar siswa.

Melihat masih rendahnya hasil belajar siswa pada pelajaran IPA di kelas IV SD Negeri No.101771 tembung, maka penulis merasa tertarik untuk melakukan penelitian yang berjudul "Upaya Meningkatkan Hasil Belajar Ilmu Pengetahuan Alam Materi Energi Alternatif Dengan Menggunakan Media Gambar Siswa Kelas IV SD Negeri No.101771 Tembung".

Berdasarkan latar belakang masalah di atas maka permasalahan yang dapat diidentifikasi adalah:

1. Hasil belajar ilmu pengetahuan alam siswa rendah.

2. Penggunaan media oleh guru dalam pembelajaran masih belum maksimal, termasuk penggunaan media gambar pada pembelajaran IPA.

3. Kurangnya keterampilan guru untuk membuat media gambar pada pembelajaran IPA.

Agar penelitian ini dapat dilakukan dengan baik dan terarah, maka penulis membatasi masalah yang hendak diteliti. Adapun batasan masalah dalam penelitian ini adalah penggunaan media gambar terhadap hasil belajar ilmu pengetahuan alam siswa kelas IV SD Negeri No.101771 Tembung.

Melihat permasalahan di atas maka rumusan masalah dalam penelitian ini adalah "Apakah dengan menggunakan media gambar dapat meningkatkan hasil belajar ilmu 
pengetahuan alam siswa kelas IV SD Negeri No.101771 Tembung?"

Berdasarkan rumusan masalah di atas, maka tujuan penelitian ini adalah: Untuk meningkatkan hasil belajar ilmu pengetahuan alam dengan menggunakan media gambar siswa kelas IV SD Negeri No.101771 tembung.

\section{METODE PENELITIAN}

Penelitian dilakukan pada siswa kelas IV SD Negeri No. 101771 Tembung, kecamatan percut sei tuan, Kabupaten Deli Serdang. Penelitian ini dilaksanakan pada semester ke II selama 3 (tiga) bulan mulai dari bulan Maret 2013 (tahap persiapan) sampai dengan bulan Mei 2013.

Subjek penelitian dalam PTK ini adalah siswa kelas IV SD Negeri No. 101771 Tembung pada Tahun Ajaran 2013/2014 yang terdiri dari 2 kelas sebanyak 50 siswa dan diambil secara acak satu kelas yaitu kelas IV B sebanyak 25 siswa. Penetapan ini berdasarkan pengamatan yang telah dilakukan. Objek penelitian ini adalah sebagai upaya peningkatan proses pembelajaran siswa dalam pelajaran IPA pada energi alternatif melalui media gambar.

Jenis penelitian yang dilakukan adalah jenis penelitian dalam bentuk Penelitian Tindakan Kelas (PTK). Adapun pendekatan yang digunakan dalam penelitian ini adalah pendekatan kualitatif, yang berguna untuk mengungkapkan kelemahan-kelemahan siswa dan cara mengatasinya untuk berupaya memaparkan penggunaan media gambar melalui proses belajar mengajar dalam pembelajaran IPA.

Desain penelitian yang digunakan dalam penelitian tindakan kelas berupa refleksi awal dan observasi untuk mengindentifikasi permasalahan yang terjadi di kelas, dilanjutkan dengan pelaksanaan PTK selama dua siklus. Sesuai dengan jenis penelitian, yaitu penelitian tindakan kelas maka dalam desain penelitian ini memiliki tahapantahapan seperti yang dikemukakan oleh Suharsimi Arikunto (2008:16) secara garis besar terdapat empat tahapan yang dilalui dalam melaksanakan penelitian tindakan kelas, yaitu (1) perencanaan (planning), (2) pelaksanaan (acting), (3) pengamatan (observing), dan (4) refleksi (reflecting).

Penelitian ini memiliki beberapa tahap pelaksanaan tindakan yang dijabarkan sebagai berikut:

Perencanaan

Kegiatan yang dilakukan dalam perencanaan adalah:

a. Mempersiapkan rencana pelaksanaan pembelajaran dengan pokok bahasan energi alternatif.

b. Mempersiapkan media gambar.

c. Menyusun aspek yang dinilai dalam lembar observasi untuk siswa dan guru, guna mengamati proses pembelajaran.

d. Menyusun alat evaluasi, untuk mengetahui tingkat keberhasilan 


$\begin{array}{lrr}\text { yang dicapai siswa } & \text { dalam } \\ \text { setiap siklus } & \text { dengan } \\ \text { diterapkannya dalam } & \text { proses } \\ \text { pembelajaran } & & \text { dengan } \\ \text { menggunakan media gambar. }\end{array}$

Pelaksanaan

Kegiatan yang dilaksanakan dalam tahap ini adalah melaksanakan rencana pembelajaran yang telah dilaksanakan, berupa proses pembelajaran. Pelaksanaan setiap siklus sebanyak 2 kali pertemuan.

Adapun kegiatan yang dilakukan dalam pelaksanaan tindakan ini meliputi:

Kegiatan awal

a. Guru melakukan apersepsi (pemberian pretest kepada siswa).

b. Guru memberikan motivasi dan menyampaikan tujuan pembelajaran kepada siswa.

c. Guru menyampaikan materi pembelajaran.

Kegiatan Inti

a. Guru menjelaskan pengertian energi alternative.

b. Guru menjelaskan berbagai bentuk energi alternatif dengan menggunakan media gambar.

c. Guru menjelaskan cara kerja beberapa contoh energi alternatif melalui media gambar.

d. Siswa ditunjuk ke depan kelas untuk menunjukkan contohcontoh energi alternatif melalui media gambar. e. Guru menyuruh beberapa siswa ke depan kelas untuk menjelaskan cara kerja beberapa contoh energi alternatif melalui media gambar.

f. Guru menjelaskan kelebihan penggunaan energi alternatif.

g. Guru menyebutkan kesulitan dalam pemanfaatan energi alternatif.

h. Guru memberikan kesempatan bertanya kepada siswa tentang materi yang belum dipahami.

Kegiatan Akhir

a. Siswa dan guru bersama-sama menyimpulkan materi pelajaran yang telah dipelajari.

b. Siswa diberikan tugas untuk mengerjakan soal.

\section{Observasi}

Observasi yang dilakukan monitoring pada proses pembelajaran di kelas secara langsung. Kegiatan ini yang diamati meliputi aktivitas guru dan siswa dalam pembelajaran. Observasi ini bertujuan untuk mengetahui kesesuaian tindakan dengan rencana yang telah disusun dan guna mengetahui sejauh mana pelaksanaan tindakan dapat menghasilkan perubahan yang sesuai dengan yang dikehendaki.

\section{Refleksi}

Kegiatan refleksi dilakukan dengan mempertimbangkan pedoman 
mengajar yang dilakukan serta melihat kesesuaian yang dicapai dengan yang diinginkan dalam pembelajaran yang pada akhirnya ditemukan kelemahan dan kekurangan untuk kemudian diperbaiki dalam siklus kedua. Setelah siklus pertama dilakukan dan belum maksimal, maka dalam hal ini dilaksanakan siklus II dengan tahapan yang sama sebagai berikut:

Teknik Pengumpulan Data

Untuk mengetahui hasil belajar siswa dengan menggunakan media gambar pada materi energi alternatif, peneliti melakukan pengumpulan data dengan menggunakan tes dan observasi.

a. Tes

Tes adalah alat untuk memperoleh data tentang kemampuan para siswa dengan cara pemberian soal. Soal-soal yang diberikan sebanyak 10 butir soal dalam pilihan berganda yang memuat semua materi energi alternatif yang telah dipelajari. Pemberian tes dibagi dalam 2 (dua) bagian yaitu post tes hasil belajar I dan post tes hasil belajar II, yang diambil dari buku paket IPA.

\section{b. Observasi}

Observasi dilakukan untuk mengamati seluruh kegiatan dan perubahan yang terjadi pada saat dilakukannya tindakan. Observasi yang dilakukan berupa pengamatan terhadap seluruh kegiatan proses belajar mengajar dan bertujuan untuk mengetahui perubahan yang terjadi saat dilakukan tindakan.

Teknik Analisis Data

Analisis data ini digunakan untuk mengetahui berhasil atau tidaknya tindakan yang dilakukan dalam penelitian ini. Hal ini dilihat seberapa persenkah tingkat keberhasilan yang dicapai dilihat dari perubahan siswa dalam menyera materi pelajaran.

Untuk menganalisis data yang diperoleh dari hasil tes dapat digunakan rumus:

a. Daya serap individu

$\mathrm{PPH}=$

$\frac{\mathrm{B}}{\mathrm{N}} \times 100 \%$

(Sudijono,

2008:318)

Keterangan:

PPH : Persentase Penilaian Hasil

B : Skor yang diperoleh siswa

$\mathrm{N}$ : Skor total

\section{HASIL DAN PEMBAHASAN}

\section{Hasil dan Pembahasan Siklus I}

Sebelum

perencanaan

tindakan dilakukan, terlebih dahulu diberikan pretest kepada 25 orang siswa, dengan tujuan mengetahui kemampuan awal siswa dan juga untuk mengetahui letak kesulitankesulitan yang dialami siswa dalam menyelesaikan soal-soal energi alternatif. Berdasarkan nilai pretest siswa di atas dapat dilihat ketuntasan siswa pada tabel berikut ini:

Tabel Nilai Hasil Belajar Pretest Siswa

\begin{tabular}{|c|c|c|c|c|}
\hline No & $\begin{array}{c}\text { Nomor } \\
\text { Responden }\end{array}$ & B & PPH (\%) & Ketuntasan \\
\hline
\end{tabular}




\begin{tabular}{|l|l|l|l|l|}
\hline 1 & 01 & 30 & 30 & Tidak Tuntas \\
\hline 2 & 02 & 70 & 70 & Tuntas \\
\hline 3 & 03 & 50 & 50 & Tidak Tuntas \\
\hline 4 & 04 & 70 & 70 & Tuntas \\
\hline 5 & 05 & 50 & 50 & Tidak Tuntas \\
\hline 6 & 06 & 60 & 60 & Tidak Tuntas \\
\hline 7 & 07 & 80 & 80 & Tuntas \\
\hline 8 & 08 & 60 & 60 & Tidak Tuntas \\
\hline 9 & 09 & 70 & 70 & Tuntas \\
\hline 10 & 010 & 50 & 50 & Tidak Tuntas \\
\hline 11 & 011 & 30 & 30 & Tidak Tuntas \\
\hline 12 & 012 & 50 & 50 & Tidak Tuntas \\
\hline 13 & 013 & 50 & 50 & Tidak Tuntas \\
\hline 14 & 014 & 40 & 40 & Tidak Tuntas \\
\hline 15 & 015 & 30 & 30 & Tidak Tuntas \\
\hline 16 & 016 & 50 & 50 & Tidak Tuntas \\
\hline 17 & 017 & 70 & 70 & Tuntas \\
\hline 18 & 018 & 60 & 60 & Tidak Tuntas \\
\hline 19 & 019 & 60 & 60 & Tidak Tuntas \\
\hline 20 & 020 & 90 & 90 & Tuntas \\
\hline 21 & 021 & 60 & 60 & Tidak Tuntas \\
\hline 22 & 022 & 30 & 30 & Tidak Tuntas \\
\hline 23 & 023 & 30 & 30 & Tidak Tuntas \\
\hline 24 & 024 & 20 & 20 & Tidak Tuntas \\
\hline 25 & 025 & 40 & 40 & Tidak Tuntas \\
\hline Jumlah & & $\mathbf{1 3 0 0}$ & $\mathbf{2 4 \%}$ \\
\hline Rata-rata Kelas & & $\mathbf{5 2}$ & \\
\hline & & & & \\
\hline
\end{tabular}

Berdasarkan pretest yang telah dilakukan diperoleh gambaran letak kesulitan siswa yaitu:

1. Siswa kurang mampu memahami berbagai bentuk energi alternatif dan cara penggunaanya.

2. Siswa kurang mengetahui cara kerja beberapa contoh dari energi alternatif.

\section{Tahap Perencanaan Tindakan I}

Penelitian tindakan ini melibatkan satu orang guru sebagai pengajar, yang skaligus menjadi kolaborator yang secara bersamasama dengan peneliti bertindak sebagai pengamat di dalam kelas. Peneliti bertugas melakukan pengamatan, mencatat segala proses kegiatan yang terjadi di dalam kelas. Kemudian hasilnya didiskusikan bersama sebagai bahan masukan bagi pelaksanaan yang kemudian akan diretıeksıkan kembalı. selanjutnya hasil refleksi itu disimpulkan dan diambil tindakan perbaikan sebagai langkah pelaksanaan berikutnya. Kemudian setelah langkah-langkah yang diambil secara bersama tersebut dilaksanakan, diadakan revisi kembali untuk melanjutkan kelangkah atau siklus selanjutnya, jika siklus I ini perlu dan harus diperbaiki.

$$
\text { Peneliti dan guru }
$$

mempersiapkan segala sesuatu yang menunjang untuk pelaksanaan tindakan penelitian sebelum memulai tindakan yang telah dirancang dalam skenario dan rencana pelaksanaan pembelajaran. Sebelum melakukan tindakan guru terlebih dahulu menerangkan tentang materi yang akan diajarkan. Pada tahap ini guru membuat alternatif masalah pembelajaran IPA dengan melaksanakan pembelajaran dengan menggunakan media gambar. Adapun langkah-langkah yang dilaksanakan pada perencanaan tindakan I ini adalah:

1. Guru menyusun dan mempersiapkan

Rencana Pelaksanaan Pembelajaran (RPP) yang telah dibuat, sebagai upaya pemecahan masalah I.

2. Guru mempersiapkan media gambar yang akan digunakan dalam proses pembelajaran pada materi energi alternatif.

3. Guru membuat lembar observasi untuk melihat kondisi kegiatan belajar mengajar dengan penggunaan media gambar. 
Nurlaili Pulungan: Upaya Meningkatkan ...

yang bervariasi yang
berhubungan dengan letak
kesulitan siswa.

5. Guru menvisun dan mempersiapka p-ISSN 2407-4934 pada setiap a] e-ISSN 2355-1747 untuk mengetahui kemampuan siswa dalam mempelajari materi energi alternatif.

\section{Tahap Pelaksanaan Tindakan I}

Pelaksanaan tindakan yang dilakukan oleh peneliti diberikan khusus pada pelajaran IPA sub pokok bahasan energi alternatif. Peneliti berusaha terlibat dalam upaya kolaboratif dengan guru kelas yang bertujuan untuk mendapatkan pemahaman yang lebih efektif terhadap perubahan yang dihasilkan dalam penggunaan media gambar yang diajarkan kepada siswa kelas IV B pada pembelajaran IPA.

Pada permulaan pengajaran guru terlebih dahulu mempersiapkan media gambar yang dibutuhkan untuk mendukung proses belajar mengajar dalam mencapai tujuan pembelajaran yang seoptimal mungkin. Dalam tindakan ini guru melaksanakan kegiatan belajar mengajar berdasarkan skenario pembelajaran yang telah disusun dan melaksanakan alternatif pemecahan yang telah telah dibuat. Selanjutnya peneliti melanjutkan ketahap pemberian tindakan. Pelaksanaan tindakan pada siklus I ini dilakukan sebanyak dua kali pertemuan.
Tiap pertemuan berlangsung selama dua jam pelajaran (2 x 35 menit). Pada tahap ini peneliti melaksanakan kegiatan pembelajaran vang merupakan pengembangan dan p-ISSN 2407-4934 ram pengajaran e-ISSN 2355-1747 ap perencanaan yaitu guru menjelaskan tentang materi energi alternatif dengan menggunakan media gambar, guru memberikan beberapa contoh bentuk energi alternatif dan cara penggunaannya. Kemudian beberapa siswa ditunjuk kedepan untuk menjelaskan kembali tentang materi energi alternatif dengan menggunakan media gambar. Kemudian guru memberikan kesempatan kepada siswa untuk bertanya tentang materi yang belum dipahaminya. Setelah itu guru memberikan penjelasan kembali tentang materi yang ditanyakan siswa dan kemudian siswa serta guru bersama-sama menyimpulkan materi pelajaran yang telah dipelajari.

Setelah pelaksanaan siklus I selesai, guru memberikan pos test (tes hasil belajar I) dengan tujuan melihat hasil belajar siswa yang telah diberikan tindakan dan guna mengetahui sudah sejauh mana pemahaman materi dan kemampuan siswa dalam menyelesaikan soal energi alternatif pada pelajaran IPA.

\section{Tahap Observasi I}

Observasi atau pengamatan dilakukan oleh peneliti dan dibantu oleh guru kelas mulai dari awal pelaksanaan tindakan pembelajaran 
yang menerapkan penggunaan media gambar dalam pembelajaran IPA pada materi energi alternatif sebagai upaya peningkatan hasil belajar siswa dalam mempelajari materi energi alternatif. Observasi ini dilakukan selama proses belajar mengajar berlangsung guna mengamati sejauh mana keberhasilan guru dan siswa dalam pembelajaran dengan menggunakan media gambar.

\section{Analisis Data}

Berdasarkan hasil tes berupa tugas menyelesaikan soal tentang energi alternatif setelah dilakukan tindakan I pada siswa melalui penggunaan media gambar. Berdasarkan nilai siklus I siswa di atas dapat dilihat ketuntasan siswa pada tabel berikut ini:

Tabel Nilai Hasil Belajar Siklus I Siswa

\begin{tabular}{|l|l|l|l|l|}
\hline No & $\begin{array}{l}\text { Nomor } \\
\text { Respon } \\
\text { den }\end{array}$ & $\mathbf{B}$ & $\begin{array}{l}\text { PPH } \\
(\%)\end{array}$ & $\begin{array}{l}\text { Ketuntas } \\
\text { an }\end{array}$ \\
\hline 1 & 01 & 50 & 50 & $\begin{array}{l}\text { Tidak } \\
\text { Tuntas }\end{array}$ \\
\hline 2 & 02 & 80 & 80 & Tuntas \\
\hline 3 & 03 & 70 & 70 & Tuntas \\
\hline 4 & 04 & 70 & 70 & Tuntas \\
\hline 5 & 05 & 50 & 50 & $\begin{array}{l}\text { Tidak } \\
\text { Tuntas }\end{array}$ \\
\hline 6 & 06 & 70 & 70 & Tuntas \\
\hline 7 & 07 & 80 & 80 & Tuntas \\
\hline 8 & 08 & 60 & 60 & $\begin{array}{l}\text { Tidak } \\
\text { Tuntas }\end{array}$ \\
\hline 9 & 09 & 90 & 90 & Tuntas \\
\hline 10 & 010 & 60 & 60 & $\begin{array}{l}\text { Tidak } \\
\text { Tuntas }\end{array}$ \\
\hline 11 & 011 & 70 & 70 & Tuntas \\
\hline 12 & 012 & 50 & 50 & $\begin{array}{l}\text { Tidak } \\
\text { Tuntas }\end{array}$ \\
\hline 13 & 013 & 70 & 70 & Tuntas \\
\hline
\end{tabular}

ESJ VOLUME 5, NO. 1, JUNI 2016

\begin{tabular}{|c|c|c|c|c|}
\hline 10 & 010 & ou & ou & $\begin{array}{l}\text { I 1dak } \\
\text { Tuntas }\end{array}$ \\
\hline 16 & 016 & 60 & 60 & $\begin{array}{l}\text { Tidak } \\
\text { Tuntas }\end{array}$ \\
\hline 17 & 017 & 70 & 70 & Tuntas \\
\hline 18 & 018 & 70 & 70 & Tuntas \\
\hline 19 & 019 & 70 & 70 & Tuntas \\
\hline 20 & 020 & 90 & 90 & Tuntas \\
\hline 21 & 021 & 80 & 80 & Tuntas \\
\hline 22 & 022 & 70 & 70 & Tuntas \\
\hline 23 & 023 & 70 & 70 & Tuntas \\
\hline 24 & 024 & 50 & 50 & $\begin{array}{l}\text { Tidak } \\
\text { Tuntas }\end{array}$ \\
\hline 25 & 025 & 50 & 50 & $\begin{array}{l}\text { Tidak } \\
\text { Tuntas }\end{array}$ \\
\hline \multicolumn{3}{|c|}{ Jumlah } & 1670 & $60 \%$ \\
\hline \multicolumn{3}{|c|}{ Rata-rata Kelas } & 66,8 & \\
\hline
\end{tabular}

Pada tabel di atas maka dapat diketahui bahwa nilai siklus I dari 25 siswa setelah mempelajari energi alternatif menunjukkan bahwa nilai terendah yang diperoleh siswa adalah nilai 50 dan tertinggi 90 . Siswa yang mencapai nilai $\leq 65$ atau tidak tuntas sebanyak 10 orang siswa (40\%) dan siswa yang mencapai $\geq 65$ atau tuntas sebanyak 15 orang siswa $(60 \%)$. Rata-rata nilai belajar siswa adalah 66,8. Tingkat ketuntasan klasikal mencapai ketuntasan sebesar $60 \%$. Hal ini menunjukkan nilai siklus I siswa masih belum berhasil karena nilai siklus I siswa masih memiliki tingkat keberhasilan belajar (ketuntasan klasikal) di bawah $80 \%$ dan siswa kelas IV SD Negeri 101771 Tembung belum tuntas mempelajari materi energi alternatif pada pelajaran IPA.

Tahap Refleksi I 
Nurlaili Pulungan: Upaya Meningkatkan ...

atas dapat disimpulkan bahwa hasil belajar siswa dari 25 orang siswa masih belum berhasil, maka perlu dilakukan per p-ISSN 2407-4934 pembelajaran gi e-ISSN 2355-1747 hasil belajar siswa. Langkah yang diambil adalah melanjutkan proses belajar mengajar pada siklus II dengan mempertimbangkan letak kesulitan-kesulitan siswa dalam memahami soal-soal khususnya pada pokok bahasan energi alternatif.

Dari hasil tes belajar yang diperoleh siswa pada siklus I diperoleh data sebanyak 15 orang siswa (60\%) yang masuk dalam kategori tuntas. Jika dibandingkan dengan tes awal yang dilakukan peneliti maka pada siklus I setelah diberi perlakuan kepada siswa maka dapat dikatakan terjadi peningkatan hasil belajar siswa pada siklus I. Walaupun demikian keberhasilan proses belajar mengajar pada siklus I belum dapat dikatakan berhasil sebab masih diperoleh data siswa yang belum mencapai ketuntasan yaitu sebanyak 10 siswa (40\%) dan siswa yang mencapai ketuntasan yaitu sebanyak 15 siswa (60\%).

Sedangkan ketuntasan klasikal yang diharapkan adalah 80\%. Maka ketuntasan belajar pada pokok bahasan energi alternatif belum tercapai. Oleh karenanya data hasil belajar siswa pada siklus I digunakan sebagai acuan untuk melakukan tindakan pada siklus II.
Pelaksanaan dan Temuan Penelitian pada Siklus II

Persentase tingkat ketuntasan klasikal siswa terhadap pembelajaran IPA khususnya pada pokok bahasan p-ISSN 2407-4934 siklus I sebesar e-ISSN 2355-1747 di peningkatan tetapi keberhasilan pada siklus I masih di bawah tingkat ketuntasan klasikal yaitu $80 \%$. Dengan demikian maka dapat dikatakan siswa kurang dalam memahami pelajaran yang telah dipelajari. Untuk itu peneliti perlu merencanakan kegiatan pembelajaran dengan menyusun rencana pembelajaran pada siklus II.

Tahap Perencanaan Tindakan II

Pada tahap ini guru membuat alternatif masalah dalam pembelajaran IPA dengan melaksanakan pembelajaran menggunakan media gambar. Adapun langkah-langkah yang dilaksanakan dalam perencanaan tindakan II ini adalah:

1. Guru menyusun dan mempersiapkan Rencana Pelaksanaan Pembelajaran (RPP) yang telah dibuat, sebagai upaya pemecahan masalah II.

2. Guru mempersiapkan media gambar yang akan digunakan dalam proses pembelajaran pada materi energi alternatif.

3. Guru membuat lembar observasi untuk melihat kondisi kegiatan belajar mengajar dengan penggunaan media gambar.

4. Guru mempersiapkan soal-soal yang bervariasi yang 
berhubungan dengan letak kesulitan siswa.

5. Guru menyusun dan mempersiapkan pos test siklus II pada setiap akhir pertemuan untuk mengetahui kemampuan siswa dalam mempelajari materi energi alternatif.

\section{Tahap Pelaksanaan Tindakan II}

Tindakan yang dilakukan oleh peneliti diberikan khusus pada pelajaran IPA pokok bahasan energi alternatif. Peneliti berusaha terlibat dalam upaya kolaboratif dengan guru kelas dengan tujuan untuk mendapatkan pemahaman yang lebih efektif terhadap perubahan yang dihasilkan dalam pelajaran energi alternatif dengan menggunakan media gambar. Sebelum memasuki kegiatan inti, guru terlebih dahulu melihat dan mencermati hasil temuan dan perbaikan yang dilakukan pada siklus I. Hal ini dilakukan untuk mengurangi kesalahan dan kelemahan dalam tindakan II sehingga hasil belajar yang didapat lebih maksimal dibandingkan siklus I. Pelaksanaan tindakan ini sama dengan pelaksanaan siklus I, hanya yang harus diperhatikan adalah peneliti harus memberi motivasi pada siswa dan perhatian lebih pada siswa yang bermasalah.

Pelaksanaan tindakan pada siklus II dilakukan sebanyak dua kali pertemuan. Tiap pertemuan berlangsung selama dua jam pelajaran (2x35 menit). Pada pertemuan kedua diberikan pos test (tes hasil belajar II) yang bertujuan melihat keberhasilan ESJ VOLUME 5, NO. 1, JUNI 2016 gambar serta melihat kesulitankesulitan yang masih dialami siswa.

\section{Tahap Observasi II}

Observasi atau pengamatan dilakukan oleh peneliti dan dibantu oleh guru kelas mulai dari awal pelaksanaan tindakan pembelajaran yang menerapkan penggunaan media gambar dalam pembelajaran IPA pada materi energi alternatif sebagai upaya peningkatan hasil belajar siswa dalam mempelajari materi energi alternatif. Adapun observasi ini tertuju pada:

\section{Analisis Data}

Berdasarkan hasil tes berupa tugas menyelesaikan soal tentang energi alternatif setelah dilakukan tindakan II pada siswa melalui penggunaan media gambar didapat data hasil belajar siswa pada pos test siklus II.

Berdasarkan nilai siklus II siswa di atas dapat dilihat ketuntasan siswa pada tabel berikut ini:

Tabel Nilai Hasil Belajar Siklus II Siswa

\begin{tabular}{|c|c|c|c|c|}
\hline No & $\begin{array}{c}\text { No. } \\
\text { Responden }\end{array}$ & B & $\begin{array}{c}\text { PPH } \\
(\%)\end{array}$ & Ketuntasan \\
\hline 1 & 01 & 70 & 70 & Tuntas \\
\hline 2 & 02 & $\begin{array}{c}10 \\
0\end{array}$ & 100 & Tuntas \\
\hline 3 & 03 & 80 & 80 & Tuntas \\
\hline 4 & 04 & 80 & 80 & Tuntas \\
\hline 5 & 05 & 70 & 70 & Tuntas \\
\hline 6 & 06 & 90 & 90 & Tuntas \\
\hline 7 & 07 & 100 & 100 & Tuntas \\
\hline 8 & 08 & 70 & 70 & Tuntas \\
\hline
\end{tabular}


Nurlaili Pulungan: Upaya Meningkatkan ...

\begin{tabular}{|c|c|c|c|c|}
\hline 12 & 012 & 70 & 70 & Tuntas \\
\hline 13 & 013 & 90 & 90 & Tuntas \\
\hline 14 & 014 & 70 & 70 & Tuntas \\
\hline 15 & 015 & \multirow{3}{*}{\multicolumn{3}{|c|}{$\begin{array}{ll}\frac{8}{7} & \text { p-ISSN } 2407-4934 \\
\frac{8}{8} & \text { e-ISSN 2355-1747 }\end{array}$}} \\
\hline 16 & 016 & & & \\
\hline 17 & 017 & & & \\
\hline 18 & 018 & 90 & 90 & Tuntas \\
\hline 19 & 019 & 80 & 80 & Tuntas \\
\hline 20 & 020 & 100 & 100 & Tuntas \\
\hline 21 & 021 & 100 & 100 & Tuntas \\
\hline 22 & 022 & 80 & 80 & Tuntas \\
\hline 23 & 023 & 90 & 90 & Tuntas \\
\hline 24 & 024 & 60 & 60 & $\begin{array}{c}\text { Tidak } \\
\text { Tuntas }\end{array}$ \\
\hline 25 & 025 & 70 & 70 & Tuntas \\
\hline \multicolumn{3}{|c|}{ Jumlah } & 2060 & $96 \%$ \\
\hline \multicolumn{3}{|c|}{ Rata-rata Kelas } & 82,4 & \\
\hline
\end{tabular}

Pada tabel di atas maka dapat diketahui bahwa nilai siklus II dari 25 siswa pada pembelajaran IPA pokok bahasan energi alternatif menunjukkan bahwa nilai terendah yang diperoleh siswa adalah nilai 60 dan tertinggi 100. Siswa yang mencapai nilai $\leq 65$ atau tidak tuntas sebanyak 1 orang siswa (4\%) dan siswa yang mencapai $\geq 65$ atau tuntas sebanyak 24 orang siswa (96\%). Rata-rata nilai belajar siswa adalah 82,4. Tingkat ketuntasan klasikal mencapai ketuntasan sebesar 96\%. Hal ini menunjukkan nilai siklus II siswa sudah berhasil dan mengalami peningkatan dari ketuntasan belajar $80 \%$. Nilai hasil belajar siswa pada siklus II sangat tinggi dibandingkan nilai keberhasilan siswa pada tes awal (pre test) dan siklus I. Dengan demikian maka dapat dikatakan bahwa hasil belajar siswa kelas IV SD Negeri 101771 tembungsudah mengalami ketuntasan belajar pada pembelajaran IPA materi energi alternatif.

Tahap Refleksi II

Dari hasil analisa data II dapat ditarik kesimpulan bahwa hasil belajar dan kemampuan siswa dalam menyelesaikan soal-soal energi alternatif mengalami peningkatan yang sangat baik ketika dilaksanakan tindakan II. Hasil belajar dari 25 orang siswa terdapat sebanyak 24 siswa (96\%) yang telah tuntas belajar dan sebanyak 1 siswa (4\%) yang belum tuntas belajar.

Dari hasil ini dapat dikatakan bahwa upaya dalam meningkatkan hasil belajar dengan menggunakan media gambar pada materi pelajaran IPA khususnya pokok bahasan energi alternatif sudah mencapai keberhasilan belajar yang sangat baik. Hal ini juga menunjukkan bahwa tindakan pembelajaran dengan penerapan penggunaan media gambar dalam pembelajaran IPA pada materi energi alternatif dapat mengaktifkan siswa dalam proses belajar mengajar sehingga siswa termotivasi untuk belajar.

Di samping itu, peneliti melihat bahwasanya keterlibatan siswa untuk bertanya dan memberikan pendapat selama kegiatan pembelajaran dapat mendorong siswa untuk berperan aktif dalam proses belajar mengajar serta memacu siswa untuk selalu antusias dalam belajar. Dengan tercapainya tingkat ketuntasan belajar siswa pada siklus II yang telah 
mengalami peningkatan, maka proses belajar mengajar tidak lagi dilanjutkan pada siklus berikutnya.

Rekapitulasi Nilai Pre Test, Siklus I, dan Siklus II

Berikut disajikan tabel dan grafik peningkatan hasil belajar siswa pada pokok bahasan energi alternatif:

Tabel Tabel Rata-rata Hasil Belajar Siswa

\begin{tabular}{|l|l|l|}
\hline No & Tes & Rata-rata \\
\hline 1 & Pre Test & 52 \\
\hline 2 & Siklus I & 66,8 \\
\hline 3 & Siklus II & 82,4 \\
\hline
\end{tabular}

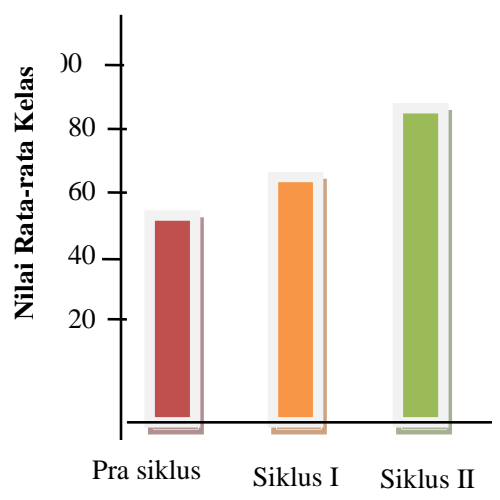

Gambar Grafik Nilai Rata-rata Peningkatan Hasil Belajar Siswa

Tabel Persentase Hasil Belajar Siswa

\begin{tabular}{|l|l|l|}
\hline No & \multicolumn{1}{|c|}{ Tes } & \multicolumn{1}{|c|}{$\begin{array}{c}\text { Persentase } \\
(\boldsymbol{\%})\end{array}$} \\
\hline 1 & Pre Test & $24 \%$ \\
\hline 2 & Siklus I & $60 \%$ \\
\hline 3 & Siklus II & $96 \%$ \\
\hline
\end{tabular}

ESJ VOLUME 5, NO. 1, JUNI 2016

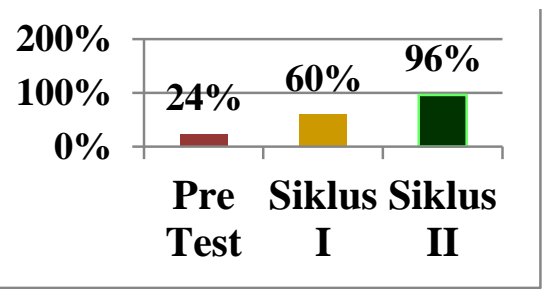

Gambar Grafik Persentase (\%) Hasil

Belajar Siswa secara Klasikal

Berdasarkan gambar di atas dapat kita lihat hasil belajar siswa berdasarkan nilai rata-rata kelas dan hasil belajar siswa berdasarkan persentase $(\%)$ secara klasikal mulai dari tes awal (pretest), siklus I sampai mengalami peningkatan di siklus II.

\section{Pembahasan Hasil Penelitian}

Berdasarkan analisis data pada siklus I dan siklus II maka yang menjadi pokok penting yang perlu dikaji adalah sebagai berikut: Berdasarkan pada tabel 3 di atas maka dapat diketahui bahwa nilai pre test dari 25 siswa sebelum dilakukan pembelajaran pada mata pelajaran IPA sebanyak 19 orang siswa $(76 \%)$ belum mencapai tingkat ketuntasan belajar (nilai $\leq 65$ ). Sedangkan 6 orang siswa (24\%) yang mencapai tingkat ketuntasan (nilai $\geq 65$ ) dengan rata-rata nilai belajar siswa adalah 52 . Tingkat ketuntasan klasikal mencapai ketuntasan sebesar 24\%. Hal ini menunjukkan nilai pre test siswa masih belum berhasil dan belum tuntas mempelajari materi energi alternatif.

\section{KESIMPULAN}


Beberapa kesimpulan yang dapat ditarik dari hasil penelitian ini adalah:

1. Penelitian dengan menggunakan media gambar dapat meningkatkan hasil belajar IPA pada materi energi alternatif siswa kelas IV SD Negeri No.101771 Nurlaili Pulungan: Upaya Meningkatkan ...

dengan menggunakan media gambar diperoleh tingkat ketuntasan hacil holaiar cerara klasikal seban p-ISSN 2407-4934 (96\%) yang e-ISSN 2355-1747

ketuntasan belajar dengan nilai rata-rata 82,4 .

Berdasarkan kesimpulan dari penelitian ini, peneliti menyarankan:

1. Untuk meningkatkan hasil belajar siswa dalam pelajaran IPA, hendaknya di dalam setiap mempelajari IPA harus menerapkan penggunaan media pembelajaran seperti media gambar agar memudahkan siswa memahami setiap materi konsep pelajaran yang diajarkan guru supaya materi pelajaran tersebut tahan lama diingat dalam setiap pribadi siswa karena penggunaan media gambar ini dapat melibatkan siswa secara langsung untuk aktif dalam belajar.

2. Kepada guru yang akan menerapkan media gambar dalam pembelajaran IPA khususnya pokok bahasan energi alternatif sebaiknya lebih mengutamakan aktivitas belajar siswa.

\section{DAFTAR RUJUKAN}

Aqib, Zainal.2009. PTK. Bandung: Yrama Widya.

Arikunto, Suharsimi.dkk. 2008. Penelitian Tindakan Kelas. Jakarta: PT Bumi Aksara.

Arsyad, Azhar. 2007. Media Pembelajaran. Jakarta: PT. Raja Grafindo Persada.

Bundu, Patta. 2006. Penilaian p-ISSN 2407-4934 Proses dan e-ISSN 2355-1747 iah dalam Pembelajaran Sains Sekolah Dasar. DEPDIKBUD.

Djaali. 2008. Psikologi Pendidikan. Jakarta: Bumi Aksara.

Haryanto. 2004. Sains untuk Sekolah Dasar Kelas IV. Jakarta: Penerbit Erlangga.

Ian. 2010. Fungsi dan Nilai Media Gambar, (online), dalam http://sekawan- media.com, diakses 30 januari 2011.

Sardiman. 2009. Interaksi dan Motivasi Belajar Mengajar. Jakarta: Rajawali Pers.

Sadiman, Arif.dkk. 2006. Media Pendidikan. Jakarta: PT. Raja Grafindo Persada.

Slameto. 2010. Belajar dan Faktor Faktor yang Mempengaruhinya. Jakarta: Rineka Cipta.

Syawaludin. 2008. Efektifitas Penggunaan Media Gambar 
Dalam Proses Pembelajaran

Sains Kelas III Pokok

Bahasan Ciri-ciri Dan

Kebutuhan Makhluk Hidup

SD Negeri 186161 Medan

Estate. Medan: UNIMED.

Tidak diterbikan. 